\title{
Soil water transformation regularity of farmland for typical crop in Beijing-Tianjin-Hebei region: Experimental and simulating analyses
}

\author{
Chuiyu Lu1 ${ }^{1}$, Qingyan Sun ${ }^{1, a}$, Guoliang Cao ${ }^{1}$, Qinghua Luan², Lingjia Yan ${ }^{1}$, Bo Zhang ${ }^{1}$, Tianchen $\mathrm{Li}^{1}$ and Bin Lai ${ }^{2}$ \\ ${ }^{1}$ State Key Laboratory of Simulation and Regulation of Water Cycle in River Basin, China Institute of Water Resources and Hydropower \\ Research, No. 1, Yuyuantan South Rd., Haidian District, Beijing 100038, China \\ ${ }^{2}$ College of Water Conservancy and Hydropower, Hebei University of Engineering, Handan 056021, China
}

\begin{abstract}
The transformation process of soil water plays an important role in the hydrological cycle, and is a link to other water processes. Study on the regularity of soil water transformation under agricultural plantation is favorable to understanding the influence of human activities on soil water conversion. Typical crop was selected in Beijing-Tianjin-Hebei(BTH) region and the study on regularity of field-scale soil water transformation was carried out by means of crop-soil water field experimental observation combined with model simulation. In the field experiment, testing and observation of irrigated and rainfed maize were simultaneously carried out in the adjacent fields respectively to form a comparative experimental study. The experimental observation data were used to establish the soil water model, which is calibrated in many aspects, such as field water content change during the maize growth period, the soil profile water content distribution at different moments, maize leaf area index and plant height. The results show that this model has an efficient simulation effect. Quantitative study on field evapotranspiration regularity, field soil water flux under irrigated and rainfed modes, impact mechanism of soil water deep seepage during maize growth period was achieved through the simulation of soil water process, and related reference conclusions were also proposed for water resources management and conservation in BTH.
\end{abstract}

\section{Introduction}

In the watershed/regional hydrological cycle system, the soil water transformation plays an important role as a link between rainfall, surface water processes and groundwater processes[1-2]. First, the soil water flux accounts for a large proportion of the total hydrological cycle flux, especially in plain regions where over $70 \%$ of the precipitation is converted to soil water first[3]; second, soil water is the main water source for direct utilization of natural vegetation and crops, which plays an irreplaceable role in the maintenance of ecological stability and agricultural production[4-6]; third, which is the most important is that, soil is the key place of all kinds of hydrological conversion processes, because the results of cyclical conversion of water in soil will directly affect the surface runoff, groundwater recharge, water consumption and other indicators of regional water resources characteristics[6]. Therefore, the study of soil water processes and transformation is an important part in researching on the hydrological cycle.

Indoor and outdoor experiments are the basic ways to study soil water and play an important role in revealing the movement and conversion rules of soil water[7-13]. However, the experiments cannot fully uncover every regularity of soil water circulation, especially the continuous change processes of in-situ soil water.
Because 1) the monitoring process of soil water is sometimes intermittent, and the measuring series also is short, so it is difficult to show the long-term change rules; 2 ) because of the spatial heterogeneity of soil water, the monitoring values often only reflect the characteristics of soil water at the measuring point scale, but cannot represent those in regional scale; 3) it is difficult to measure all processes of the soil water transformation, such as transpiration, evaporation and lateral flow, etc.; 4) some field measurements and all laboratory measurements of soil water indicators have disturbed the natural soil during the monitoring process, and cannot reflect the real conditions, such as the laboratory infiltration test of soil column[14-16]. Thus, using the mathematical model to simulate the soil water dynamic has been an important means to make up the above defects of indoor and outdoor experiments.

It is common to study the soil water processes in combination with experiment and mathematical model $[17-19,12]$. In general, the experiments and measurements provide the parameters of soil water simulation for the model building, such as soil bulk density, soil texture, and hydraulic conductivity so on, as well as supply measured data for the model calibration, such as soil water content, vegetation leaf area index, etc. $[17,10]$. The structure and principle of each model are not identical, but the core of models is unsaturated soil

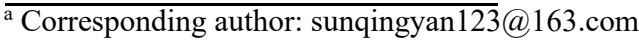


water flow equation based on the principle of momentum conservation and mass conservation, which can be divided into water balance model and hydrodynamic model[10, 20]. However, soil water transformation model for field scale and regional scale not only involves the movement of soil water in porous media, but also includes field ponding, evapotranspiration, plant growth and other related links, thus completely express the soil water dynamic transformation process.

Farmland water cycle is an important part of the watershed/regional hydrological cycle, especially in areas where agricultural production activities are severe, such as the Beijing-Tianjin-Hebei(BTH) region, and the transformation and balance of soil water are the important content in the farmland water cycle research of BTH region. In order to reveal the basic regularity of soil water transformation, we carried out field experiments and model simulation for a typical crop in BTH region.

\section{Method}

The method of crop-soil-water observation experiment combined with model simulation was used, namely, first, field experiment was used to obtain the soil parameters and some observation data related to the soil water transformation in the study site, such as soil property, crop growth status, meteorological data and shallow groundwater depth and so on. Second, the soil water transformation model was used to simulate the soil water process, and the experimental data was used to calibrate the model, to quantitatively analyse the overall variation regularity of soil water flux during the experiment.

\subsection{Field experiment}

The field experiment was carried out in an experimental station for dry farming and water saving under the Dry Farming Institute of the Hebei Academy of Agriculture and Forestry. This experimental station is located in Hujiachi Town, Hebei province, whose geographical coordinates are $115^{\circ} 42^{\prime} \mathrm{E}$ and $37^{\circ} 44^{\prime} \mathrm{N}$. The experimental fields were composed of four adjacent rectangular cornfields (Figure 1). Field 1 and field 4 were irrigated according to the irrigation times and amount of the farmland around the experiment station. Field 2 and field 3 were rainfed, and irrigation was not carried out during the experiment in order to establish experimental comparisons with field 1 and field 4. Experimental period, lasted 110 days, was from June 16 to October 3 when covered the full growth period of maize in 2016. Experimental observation items were 10 in total, which is as shown in Table 1.
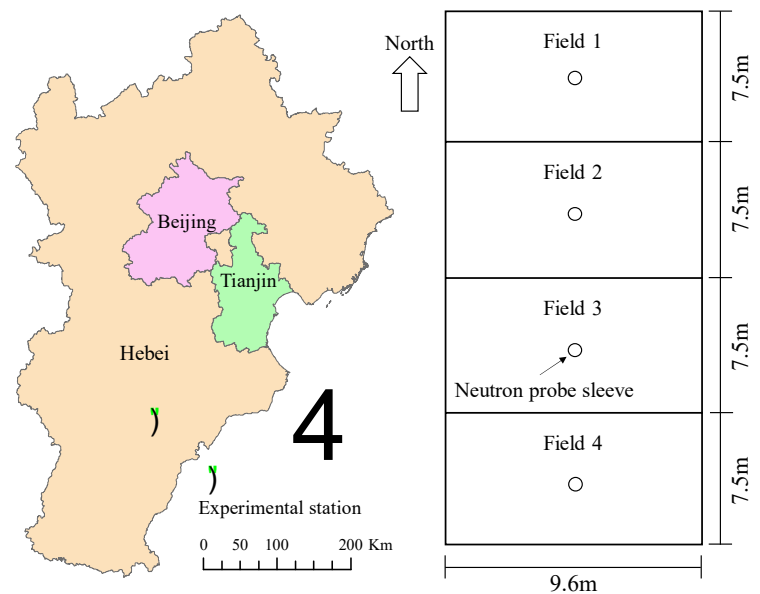

Figure 1. Location of the experimental station in the BTH region and distribution of the experimental fields. Field 1 and field 4 were irrigated, and field 2 and field 3 were rainfed. The BTH region, located in the North China Plain with extreme water shortage, is the circle of economy around the capital, and is being carried out the integration management of water resources according to the national major development strategy.

Table 1. Observation items of the field experiment during maize growth period.

\begin{tabular}{|c|c|c|c|}
\hline $\begin{array}{c}\text { Item } \\
\text { Description }\end{array}$ & $\begin{array}{c}\text { Observation } \\
\text { method }\end{array}$ & $\begin{array}{c}\text { Observation } \\
\text { Time }\end{array}$ & $\begin{array}{c}\text { Observation } \\
\text { Frequency }\end{array}$ \\
\hline $\begin{array}{c}\text { Soil } \\
\text { parameters }\end{array}$ & $\begin{array}{l}\text { Stratified } \\
\text { sampling }\end{array}$ & \begin{tabular}{|c|} 
Early \\
experimental \\
stage \\
\end{tabular} & One time \\
\hline $\begin{array}{c}\text { Meteorological } \\
\text { factors }\end{array}$ & $\begin{array}{l}\text { Meteorological } \\
\text { station in } \\
\text { experimental site }\end{array}$ & $\begin{array}{c}\text { During } \\
\text { experiment }\end{array}$ & Daily \\
\hline $\begin{array}{r}\text { Sectior } \\
\text { water col }\end{array}$ & Neutron probe & $\begin{array}{c}\text { During } \\
\text { experiment }\end{array}$ & $\begin{array}{c}\text { Every } 5 \\
\text { days or } \\
\text { more } \\
\text { frequent }\end{array}$ \\
\hline $\begin{array}{c}\text { Topsoil water } \\
\text { content }\end{array}$ & $\begin{array}{l}\text { Time-domain } \\
\text { reflectometry } \\
\text { (TDR) }\end{array}$ & $\begin{array}{c}\text { During } \\
\text { experiment }\end{array}$ & $\begin{array}{c}\text { Every } 5 \\
\text { days }\end{array}$ \\
\hline $\begin{array}{l}\text { Leaf area } \\
\text { index }\end{array}$ & $\begin{array}{l}\text { Leaf area index } \\
\text { instrument and } \\
\text { sampling } \\
\text { measurement }\end{array}$ & $\begin{array}{l}\text { During crop } \\
\text { growth }\end{array}$ & $\begin{array}{l}\text { One or two } \\
\text { times in } \\
\text { each } \\
\text { growth } \\
\text { period }\end{array}$ \\
\hline Plant h & $\begin{array}{c}\text { Sampling } \\
\text { measurement } \\
\text { using measuring } \\
\text { tape } \\
\end{array}$ & $\begin{array}{l}\text { During crop } \\
\text { growth }\end{array}$ & $\begin{array}{c}\text { Once every } \\
\text { week or } \\
\text { more } \\
\text { frequent }\end{array}$ \\
\hline $\begin{array}{l}\text { Irrigation } \\
\text { event }\end{array}$ & Record & In irrigation & $\begin{array}{l}\text { Every } \\
\text { irrigation } \\
\text { event }\end{array}$ \\
\hline $\begin{array}{c}\text { Fertilization } \\
\text { event }\end{array}$ & Record & $\begin{array}{c}\text { In } \\
\text { fertilization }\end{array}$ & $\begin{array}{c}\text { Every } \\
\text { fertilization } \\
\text { event }\end{array}$ \\
\hline $\begin{array}{c}\text { groundwater } \\
\text { depth }\end{array}$ & $\begin{array}{c}\text { Measuring rope } \\
\text { method }\end{array}$ & $\begin{array}{c}\text { During } \\
\text { experiment }\end{array}$ & $\begin{array}{c}\text { Every } 5 \\
\text { days }\end{array}$ \\
\hline Crop y & $\begin{array}{c}\text { Sampling } \\
\text { measurement }\end{array}$ & $\begin{array}{l}\text { In crop } \\
\text { harvest }\end{array}$ & One time \\
\hline
\end{tabular}

Alluvial soil was the major soil type in the experimental site, whose soil layer was deep and which was mainly composed of loamy soil as well as some sandy and clayey soil. Prior to the experiment, the soil 
parameters of the experimental fields were sampled and measured by means of cutting ring sampling at the interval of $20 \mathrm{~cm}$ at a total depth of $200 \mathrm{~cm}$. The parameters of soil dry volume weight, soil water content and soil texture were measured and as shown in Table 2.

Table 2. Soil parameters at the experimental site

\begin{tabular}{|c|c|c|c|c|c|c|}
\hline \multirow{2}{*}{$\begin{array}{l}\text { Depth } \\
\text { interval } \\
(\mathrm{cm})\end{array}$} & \multirow{2}{*}{$\begin{array}{c}\text { Dry } \\
\text { volume } \\
\text { weight } \\
(\mathrm{g} / \mathrm{cm} 3)\end{array}$} & \multirow{2}{*}{$\begin{array}{c}\text { Field } \\
\text { capacity } \\
(\%)\end{array}$} & \multicolumn{3}{|c|}{$\begin{array}{c}\text { Soil texture } \\
(\%)\end{array}$} & \multirow{2}{*}{ Remarks } \\
\hline & & & Clay & Silt & Sand & \\
\hline $0-20$ & 1.45 & 0.22 & 16 & 57 & 27 & Silt loam \\
\hline $20-40$ & 1.52 & 0.32 & 16 & 48 & 36 & Loam \\
\hline $40-60$ & 1.41 & 0.35 & 30 & 43 & 27 & $\begin{array}{c}\text { Clay loam, } \\
\text { waterloggogenic } \\
\text { horizon between } \\
39 \sim 43 \mathrm{~cm} \\
\end{array}$ \\
\hline $60-80$ & 1.38 & 0.38 & 39 & 43 & 19 & \begin{tabular}{|c|} 
Clay loam, \\
waterloggogenic \\
horizon between \\
$50 \sim 75 \mathrm{~cm}$ \\
\end{tabular} \\
\hline $80-100$ & 1.39 & 0.34 & 28 & 40 & 32 & Clay loam \\
\hline $100-120$ & 1.57 & 0.36 & 28 & 40 & 32 & Clay loam \\
\hline $120-140$ & 1.50 & 0.38 & 29 & 39 & 32 & Clay loam \\
\hline $140-160$ & 1.43 & 0.38 & 29 & 39 & 32 & Clay loam \\
\hline $160-180$ & 1.43 & 0.37 & 30 & 44 & 26 & Clay loam \\
\hline $180-200$ & 1.47 & 0.42 & 32 & 43 & 25 & Clay loam \\
\hline
\end{tabular}

There was a dedicated meteorological observation station in the experimental site, whose observation elements mainly included rainfall, highest/lowest temperature, relative humidity, wind speed, solar radiation and other daily scale data. The change of soil water content was the key observation item in the experiment. A $2 \mathrm{~m}$-length neutron probe sleeve was buried in the center of each field (Figure 1). In general, soil water content was observed every 5 days and was additionally measured once before and after a rainfall. Water content of section was observed at $20 \mathrm{~cm}$ interval in section. Due to the poor accuracy of the neutron probe in observing the surface soil water content, the soil water content of $0 \sim 20 \mathrm{~cm}$ soil layer was measured by time-domain reflectometry (TDR) instead. During the experiment, the leaf area index of maize was measured five times by the leaf area index instrument and the plant height was measured 14 times using the measuring tape in the whole growth period. Field 1 and 4 were irrigated $750 \mathrm{~m} 3 / \mathrm{hm} 2$ (depth about $75 \mathrm{~mm}$ ) once on July 29 . Fields were fertilized two times, respectively compound base fertilizer $600 \mathrm{~kg} / \mathrm{hm} 2$ on June 26th and topdressing urea $74 \mathrm{~kg} / \mathrm{hm} 2$ on July 29 th. The change of underground water depth was observed by the method of measuring rope in a shallow well about $50 \mathrm{~m}$ away from the southwest corner of the experimental plots at a frequency of once 5 days. The change of groundwater depth was observed at a frequency of once 5 days using measuring rope in a shallow well about 50m away from the southwest corner of the experimental fields. As this well was also used for irrigation, the measured data were only for reference. The maize was harvested On October 3, 2016, and its yield was estimated by the sampling $\&$ weighting method.

\subsection{Soil water transformation model}

Through the field experiment and observation, we can get the main data of meteorology, soil moisture and crop growth during the growing season, but most of them are intermittent. In order to further reveal the continuous process of soil water transformation in field scale and make up for the unobservable flux, the soil water simulation tool was used to perform inversion. The simulation tool used in our study was the soil water simulation module of the MODCYCLE[21-23], a distributed hydrological model, which was independently developed. The module calculates soil water processes layer by layer with the one-dimensional semiempirical/semi-dynamic model at a day-scale. The simulation principles include precipitation/irrigation, infiltration/runoff, layered seepage of soil water, evapotranspiration, lateral flow, phreatic water evaporation and plant growth (Figure 2), which are briefly described as follows:

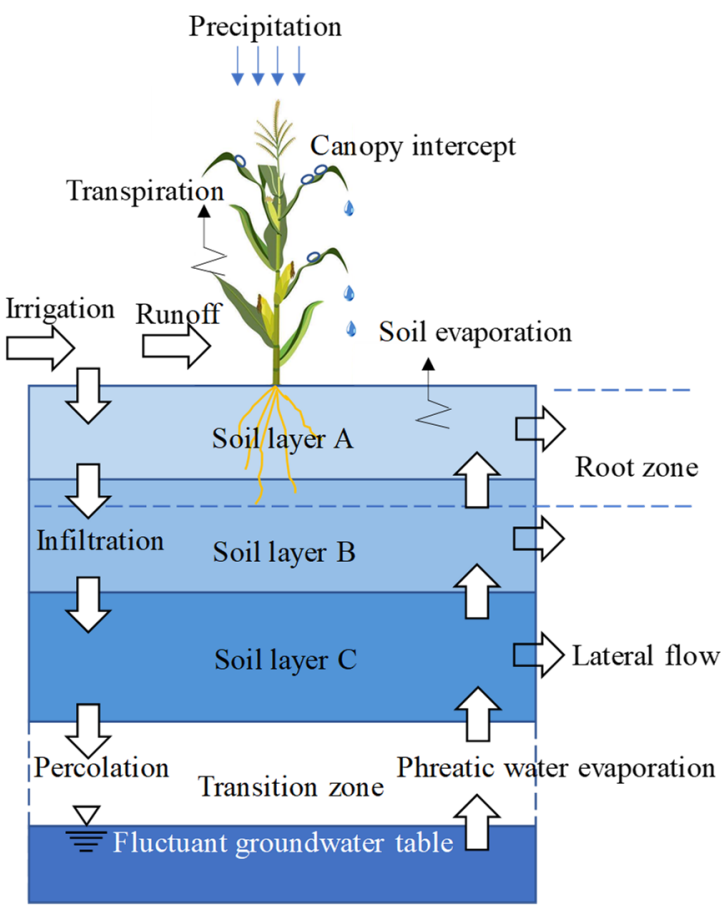

Figure 2. Schematic diagram of soil water transformation in farmland

\subsubsection{Precipitation/irrigation}

The model determines whether the precipitation on the day is rainfall or snowfall through the snowfall base temperature parameter, and the snow accumulation and melting processes are simulated using degree-day factor method[24]. The canopy interception process of rainfall is considered in the model. Given that the vegetation has the maximum canopy interception capacity when the vegetation is fully grown, the interception capacity of the 
vegetation was linearly related to the leaf area index. The total of net rainfall, snowmelt and irrigation water is the potential infiltration volume, and is separated into actual infiltration and runoff in the infiltration/runoff simulation.

\subsubsection{Infiltration/runoff}

The infiltration/runoff process is simulated by an improved Green-Ampt method with a ponding mechanism on the land surface, and the iterative calculation period was half an hour. The Green-Ampt method was used to calculate the actual infiltration flux through the soil surface on the day. The ponding volume on the land surface is calculated by the difference between the potential and the actual infiltration volume. The ponding volume exceeding the maximum water depth (which is the input parameter of the model) on the land surface is considered as runoff. The volume that do not infiltrate on the day will be considered as the potential infiltration volume for infiltration/runoff calculation in the following day. There are two purposes of introducing the ponding mechanism on the land surface, the first is to simulate the retention phenomenon in natural low-lying land, and the second is to simulate the water blocking effect of the farmland ridge, making the simulation of infiltration/runoff process close to reality.

\subsubsection{Evapotranspiration}

Evapotranspiration included four aspects, namely, evaporation of canopy intercept, snow sublimation, soil evaporation and plant transpiration. Penman-Monteith formula is used in the model firstly to calculate the transpiration of reference crop on the day, and then the evaporation of canopy intercept and snow sublimation are reduced from the transpiration of reference crop in turn. The remaining evaporation is assigned to all soil layers through the evaporation distribution curve and soil evaporation is calculated based on the current stratified water content and the vegetation coverage of the soil. The potential transpiration of vegetation is also calculated by the Penman-Monteith formula, but the aerodynamic impedance and vegetation community impedance parameters depend on the specific crop condition. Potential transpiration is distributed over the range of crop root zone, and the actual vegetation transpiration is calculated based on the current stratified water content of the soil.

\subsubsection{Layered seepage of soil water}

The movement of water from a soil layer to the underlying soil layer is controlled by the field capacity. When the water content in a soil layer is greater than the field capacity (there is gravity water), water will infiltrate into the underlying soil layer. The infiltration rate is related to saturated hydraulic conductivity of the soil layer, and the formula is:

$$
\operatorname{seep}_{l y}=10 \cdot D\left(\theta-\theta_{F C}\right) \cdot\left[1-\exp \left(-24 K_{s}\right)\right]
$$

Where, seep $_{l y}$ is the seepage volume of the soil layer ( $\mathrm{mm}$ $\mathrm{H}_{2} \mathrm{O} /$ day); $D$ is the thickness of the soil layer $(\mathrm{cm}) ; \theta$ is the water content of the soil layer $(-), \theta_{F C}$ is the water content in field capacity (-); $K_{s}$ is the saturated hydraulic conductivity of the soil layer $(\mathrm{mm} / \mathrm{hr})$. The water through the bottom of the soil profile enters into the transition zone between soil water and groundwater, and its recharge to groundwater is calculated by an exponential decay weighting function[25].

\subsubsection{Lateral flow}

When there is gravity water in the soil layer, the lateral flow is calculated as the terrain slope. The formula is:

$$
L a t_{l y}=48 \cdot \frac{\left(\theta-\theta_{F C}\right) D}{\left(\theta_{S}-\theta_{F C}\right) L_{s l p}} \cdot K_{S} \cdot \sin (s l p)
$$

Where, Lat $_{l y}$ is lateral flow volume in the soil layer ( $\mathrm{mm} \mathrm{H}_{2} \mathrm{O} /$ day), $\theta_{S}$ is the saturated water content in the soil layer (-), $D$ is thickness of the soil layer $(\mathrm{m}), L_{s l p}$ is the average length from field to nearby ditch $(\mathrm{m}), K_{s}$ is the saturated hydraulic conductivity of the soil layer $(\mathrm{mm} / \mathrm{hr})$, $s l p$ is the average slope of the field (-).

\subsubsection{Phreatic water evaporation}

Phreatic water evaporation is calculated by Avarianov's empirical formula (3). The phreatic water evaporation is one of the sources of soil water recharge, which is calculated in this model after the calculation of the evapotranspiration in all layers of the soil, and proportionally recharged to each soil layer according to the actual evaporation in each soil layer on the day.

$$
E_{g}=K \cdot E_{0}\left(1-\frac{d}{D_{\max }}\right)^{p}
$$

Where, $E_{g}$ is the evaporation from phreatic water $(\mathrm{mm}) ; K$ is the phreatic water evaporation coefficient (-); $E_{0}$ is the potential evaporation of the soil water $(\mathrm{mm}) ; D_{\max }$ is the ultimate depth of phreatic water for evaporation (m); $d$ is the depth of phreatic water (m); $p$ is the phreatic water evaporation index (-).

\subsubsection{Plant growth}

Plant growth is based on the heat unit theory[26], that is, plants have quantifiable caloric requirements, which are related to maturation time. The calculation of plant potential biomass is based on the method proposed by Monteith[3], and the stress effects of temperature and water on plant growth are also considered. In addition to plant biomass growth, leaf area index, canopy height and plant root growth are also simulated in the model.

\section{Simulation and calibration}

During the experiment, the planting date of maize was June 16, 2016 and the harvest date was October 3, lasting 107 days in total. In order to eliminate the effect of the 
initial conditions, the simulation start date was set to April 1,2016 . The main input data of the model included daily meteorological, crop parameter, soil parameter, irrigation information and so on. The main soil and crop parameters used in the simulation are shown in Table 3.

Table 3. Main soil and crop parameters in the model

\begin{tabular}{|c|c|c|c|}
\hline \multicolumn{4}{|c|}{ Soil parameters } \\
\hline $\begin{array}{c}\text { Depth } \\
\text { interval } \\
(\mathrm{cm})\end{array}$ & $\begin{array}{c}\text { Saturated } \\
\text { hydraulic } \\
\text { conductivity } \\
(\mathrm{mm} / \mathrm{hr})\end{array}$ & $\begin{array}{c}\text { Water content at } \\
\text { wilting point (\%) }\end{array}$ & $\begin{array}{c}\text { Saturated water } \\
\text { content (\%) }\end{array}$ \\
\hline $0-20$ & 10.8 & 0.09 & 0.45 \\
\hline $20-40$ & 8.2 & 0.10 & 0.43 \\
\hline $40-60$ & 2.1 & 0.17 & 0.47 \\
\hline $60-80$ & 1.5 & 0.21 & 0.48 \\
\hline $80-100$ & 5.6 & 0.16 & 0.48 \\
\hline $100-120$ & 5.1 & 0.17 & 0.41 \\
\hline $120-140$ & 4.5 & 0.18 & 0.43 \\
\hline $140-160$ & 4.2 & 0.16 & 0.46 \\
\hline $160-180$ & 3.9 & 0.17 & 0.46 \\
\hline $180-200$ & 3.1 & 0.19 & 0.45 \\
\hline \multicolumn{4}{|c|}{ Crop parameters (Maize) } \\
\hline
\end{tabular}

\begin{tabular}{|c|c|}
\hline Growth base temperature $\left({ }^{\circ} \mathrm{C}\right)$ & 8 \\
\hline Optimum growth temperature $\left({ }^{\circ} \mathrm{C}\right)$ & 25 \\
\hline Maximum leaf area index $(-)$ & 5.9 \\
\hline Maximum plant height $(\mathrm{m})$ & 2.5 \\
\hline $\begin{array}{c}\text { Radiation efficiency coefficient } \\
(\mathrm{kg} / \mathrm{ha}) /(\mathrm{MJ} / \mathrm{m} 2)\end{array}$ & 47.0 \\
\hline Maximum root depth $(\mathrm{m})$ & 0.60 \\
\hline Light extinction coefficient $(-)$ & 0.65 \\
\hline Minimum stoma resistance $(\mathrm{sm}-1)$ & 143 \\
\hline Maximum canopy intercept capacity $(\mathrm{mm})$ & 2.0 \\
\hline
\end{tabular}

Note: Field capacity is shown in Table 2.

After the model calibration, the comparison between the simulated average water content and the measured value of the soil profile above the depth of $2 \mathrm{~m}$ is shown in Figure 3. Figure 3(a) shows the comparison between the simulated and measured data of irrigated fields (take Field 1 as an example), and Figure 3(b) shows that of rainfed fields (take Field 3 as an example). It can be seen from the figures that the simulated curves of the soil water content are basically the same with measured values. The average value of the Nash efficiency coefficient is 0.87 and the mean value of the related coefficients is 0.94 .
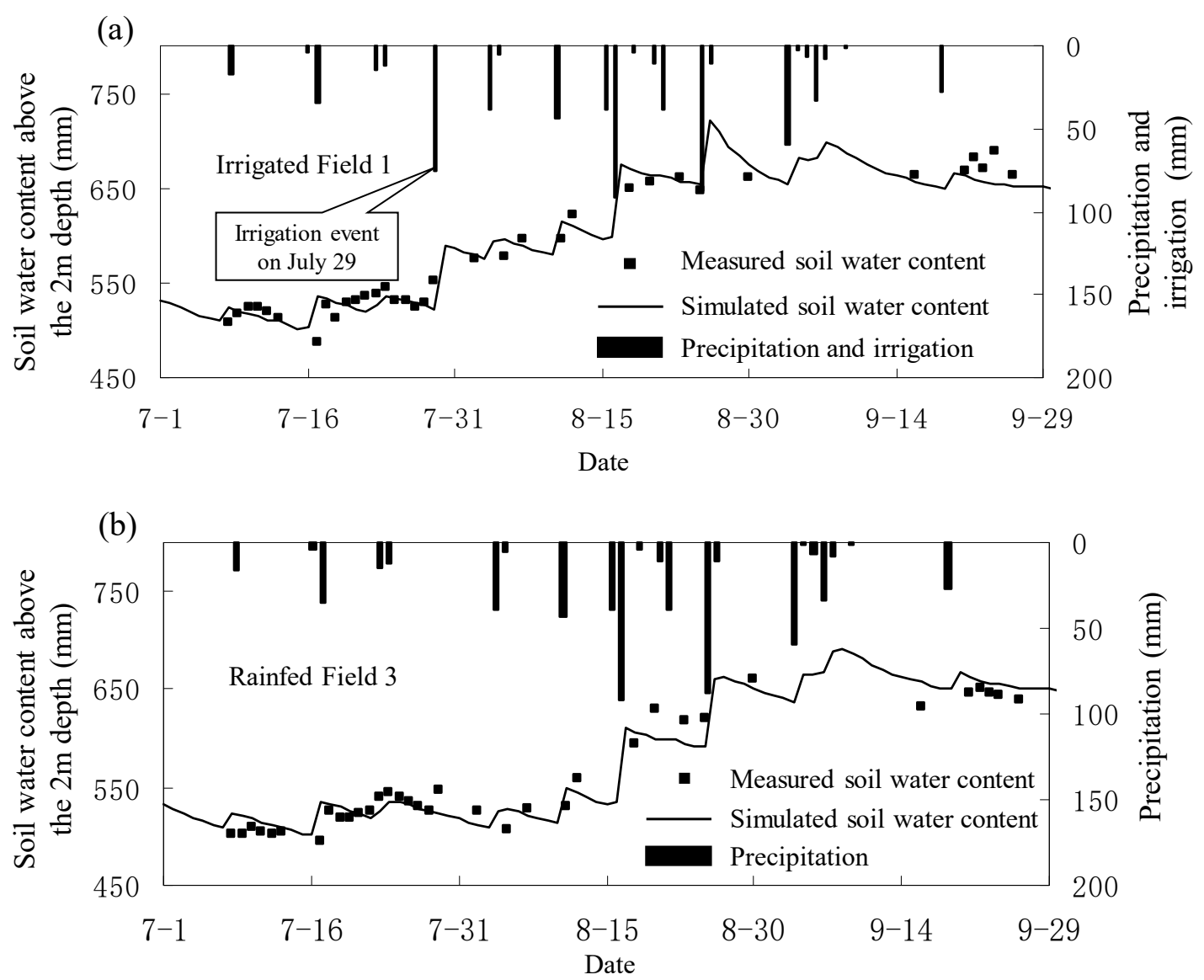

Figure 3. Comparison between the simulated and measured water content in the soil profile above the $2 \mathrm{~m}$ depth for the irrigated field 1 (a) and the rainfed field 3 (b).

In order to analyse the distribution of water content in the soil profile at a certain moment, soil water content data on July 13, July 20, July 26, August 7, August 12 and August 25 were selected to conduct the comparison between simulated and measured value, which is shown in Figure 4. The Figure 4(a) shows the soil profile water content distribution of irrigated field and Figure 4(b) shows that of rainfed field. It can be seen from the figures that there is a good correlation between the trend of the simulated and the measured values in both irrigated and rainfed fields. 
(a) Soil water content $(\%)$
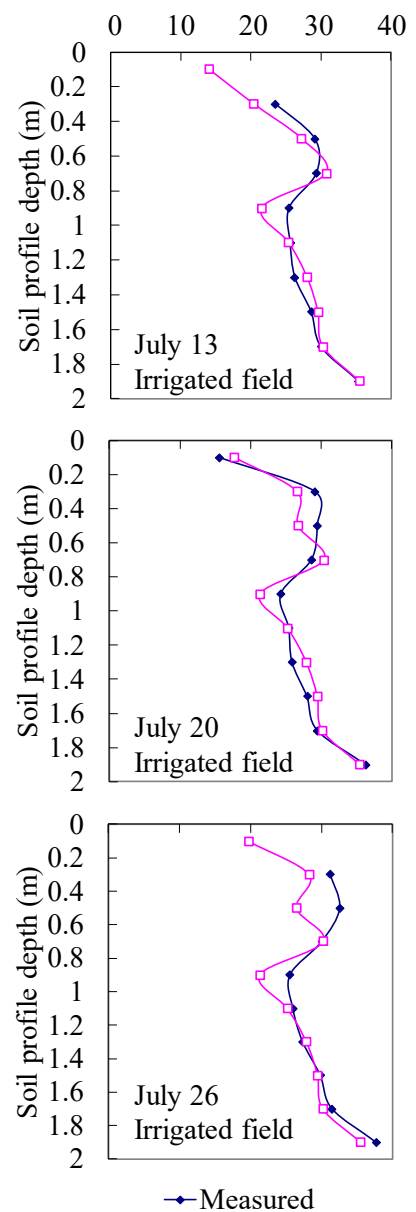

(b) Soil water content $(\%)$
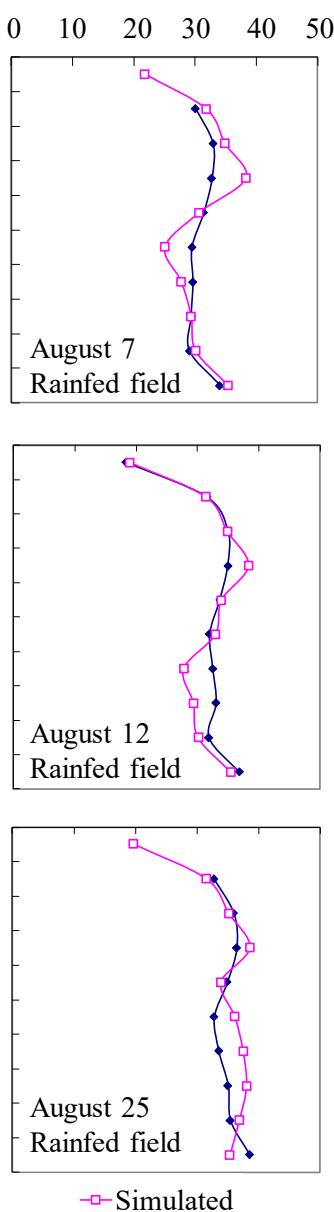

(a)

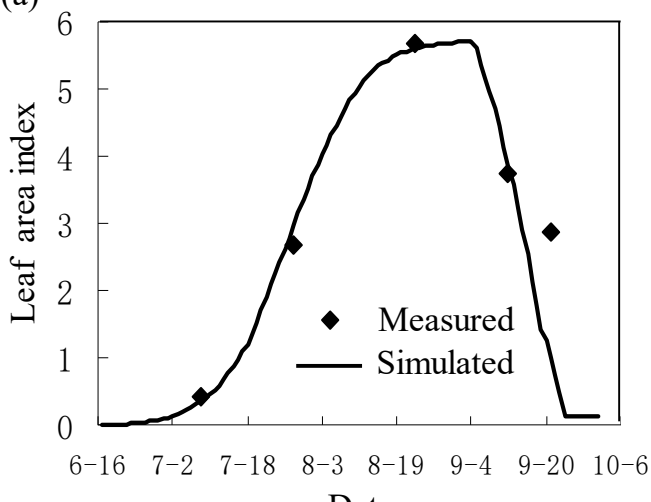

Date
Figure 4. Comparison between the simulated and measured water content distribution in the soil profile above the $2 \mathrm{~m}$ depth on July 13, July 20 and July 26 for the irrigated field (a) and on August 7, August 12 and August 25 for the rainfed field (b).

The comparison between simulated and measured values of leaf area index and plant height during the growth period of maize is shown in Figure 5. It should be noted that due to adequate rainfall during the experiment, the experimental observation data indicated that the growth of maize in irrigated fields and rainfed fields was basically the same. The maize yield in irrigated fields and rainfed fields were $8490 \mathrm{~kg} / \mathrm{hm} 2$ and $8310 \mathrm{~kg} / \mathrm{hm} 2$ respectively. Considering the measurement error, the difference between them could be neglected. In the figure, only the simulation results of irrigated field 1 were given. The day-by-day simulation values and the measured values of leaf area index and plant height during the whole growth period of maize achieved good simulation results in both on the curve trend and the values at different moments, indicating that the model used was effective in describing the crop growth.

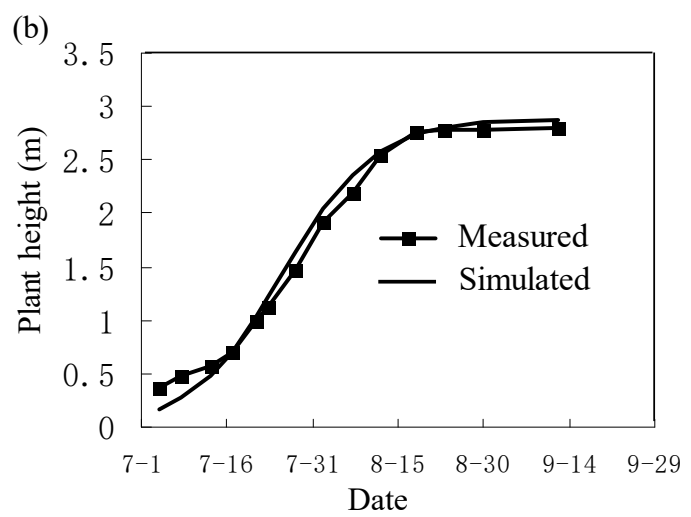

Figure 5. Comparison of measured and simulated values for leaf area index (a) and plant height (b) during the growth period of maize in field 1.

In summary, calibration was done on model parameters by comparing the measured value and simulated values of the profile water content change with time, soil profile water content distribution, leaf area index and plant height at different moments during the maize growth period and the results showed that the simulation results in this model were reliable, so it could be used to analyse the change regularity of soil water transformation in the field.

\section{Soil water transformation regularity}

\subsection{Soil water content change}

The field experiment was divided into irrigated and rainfed conditions, which was useful to carry out the comparative study on the farmland water cycle regularity under irrigation conditions. In the simulation, the change process of water content in soil profile above $2 \mathrm{~m}$ depth under two experimental conditions during the maize growth period was shown in Figure 6. Before the irrigation on July 29,2016 , the change regularities of soil water content in irrigated fields and rainfed fields were consistent. After the irrigation event, the soil water 
content under two conditions appeared difference, however, this difference tended to be gradually reduced as the time went by, and soil water content became consistent around September 9, 2016 for both conditions. The reason was analysed in two parts. One was that the soil water content in irrigated fields was increased after irrigation, and the evapotranspiration would be slightly larger than that of rainfed fields in the later stage. The other one was the frequency and volume of rainfall were increased after irrigation, so the soil water content in both types of fields was increased, and after a period of accumulation, the soil water content was gradually approached to the field capacity of the soil profile. The soil water content in irrigated fields exceeded the field capacity first and then formed deep seepage losses to recharge the groundwater, while the soil water content in rainfed fields continued to increase, thus, the soil water content curve of two types of fields returned to consistent trend.

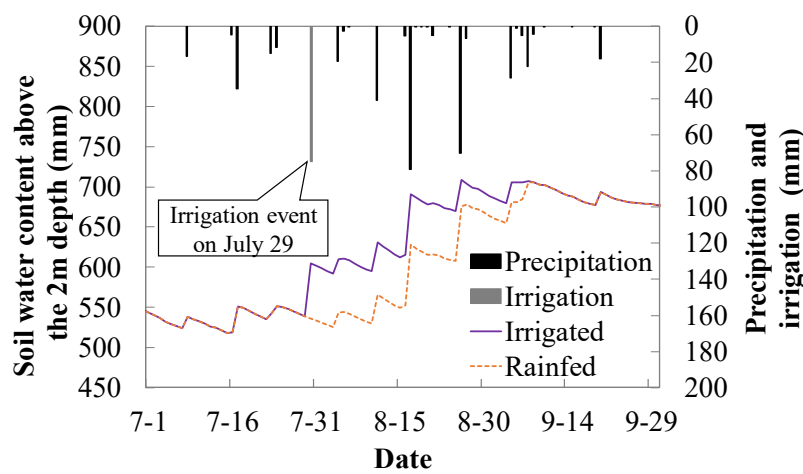

Figure 6. Changes of soil water content above the $2 \mathrm{~m}$ depth in irrigation and rainfed fields during simulation

\subsection{Soil water transformation flux}

One of the advantages of the soil water transformation model is that water flux can be analysed, which is difficult to achieve by general experimental methods. During the growth period of maize (June 16, 2016 to October 3, 2016), the simulation results of the water flux for the irrigated and rainfed fields are shown in Table 4.

Table 4. Water flux in soil profile of $0 \sim 2 \mathrm{~m}$ depth during maize growth period (Unit: $\mathrm{mm}$ )

\begin{tabular}{|c|c|c|c|}
\hline \multirow{4}{*}{ Recharge } & Items & $\begin{array}{c}\text { Irrigated } \\
\text { fields }\end{array}$ & $\begin{array}{c}\text { Rainfed } \\
\text { fields }\end{array}$ \\
\cline { 2 - 4 } & Rainfall volume & 481.5 & 481.5 \\
\cline { 2 - 4 } & Irrigation volume & 75.0 & 0.0 \\
\cline { 2 - 4 } & $\begin{array}{c}\text { Phreatic } \\
\text { evaporation }\end{array}$ & 0.0 & 0.0 \\
\hline \multirow{4}{*}{ Discharge } & $\begin{array}{c}\text { Evaporation of } \\
\text { canopy intercept }\end{array}$ & 24.8 & 24.9 \\
\cline { 2 - 4 } & Soil evaporation & 108.3 & 103.0 \\
\cline { 2 - 4 } & Plant transpiration & 183.5 & 183.5 \\
\cline { 2 - 4 } & Deep seepage & 75.9 & 12.1 \\
\cline { 2 - 4 } & Surface runoff & 0.0 & 0.0 \\
\cline { 2 - 4 } & Lateral flow & 0.0 & 0.0 \\
\hline $\begin{array}{c}\text { Storage } \\
\text { change }\end{array}$ & $\begin{array}{c}\text { Change of soil } \\
\text { water content }\end{array}$ & 118.6 & 118.6 \\
\hline
\end{tabular}

\begin{tabular}{|c|c|c|c|}
\hline $\begin{array}{c}\text { Simulation } \\
\text { error }\end{array}$ & 0.0 & 0.0 \\
\hline
\end{tabular}

During the growth period of maize, the total rainfall was $481.5 \mathrm{~mm}$. Because of the field ridge, the irrigation water all participated in the vertical process in the field, surface runoff was not found during the experiment. The experimental site is in the plain area, and the slope of the ground surface is very small, so the lateral flow process is not considered in the simulation process. In addition, the groundwater depth in the experimental site is about $6 \sim 7 \mathrm{~m}$, so the phreatic water evaporation process can be neglected.

After the analysis of soil water flux and the comparison between irrigated and rainfed fields, the following regularities can be obtained. First, during the experiment, the rainfall was quite abundant, and there was nearly no water stress during the growth of the maize, so the crop transpiration (the root water uptake) of irrigated and rainfed fields was the same. Second, irrigation would impose certain impact on the evaporation of surface soil, but the impact was limited. The surface soil evaporation of irrigated fields was about $5.3 \mathrm{~mm}$ larger than that of rainfed fields, which was related to the relatively high water content of soil surface in irrigated fields. Third, the irrigation volume had a significant impact on increasing the deep seepage of the soil. During this experiment, the deep seepage volume of irrigated fields increased by about $63.8 \mathrm{~mm}$ as compared with the deep seepage of rainfed fields, that is, $85 \%$ of the $75 \mathrm{~mm}$ irrigation water volume pumped from well returned to the groundwater through the soil water seepage.

\subsection{Soil water deep seepage}

The deep seepage of soil water is the main source of groundwater recharge, which is of special importance to the BTH Plain with over-exploitation of groundwater. Deep seepage of soil water is hard to be observed through general experiments, but the soil water simulation tool developed in this paper can be used for quantitative analysis on it. The deep seepage process of soil water during the maize growth in this experiment is shown in Figure 7. The simulation results showed that the deep seepage of soil water was not occurred in every rainfall, and the early accumulation of soil moisture played an important role in the deep seepage of soil water. During the simulation, the deep seepage of soil water only occurred in the late stage of maize growth. It can be seen from the change process of soil water content (Figure 6) that, the accumulation of rainfall in soil in early stage was the basis of deep seepage in the later stage. The deep seepage would not occur until the soil water content had accumulated to a certain volume. It was also indicated in the figure that deep seepage occurred in both irrigated and rainfed fields, but the deep seepage started in irrigated fields was earlier than that in rainfed fields, and the volume was also much larger than that in rainfed fields, because the accumulation volume of soil water in early stage was increased by the irrigation. 


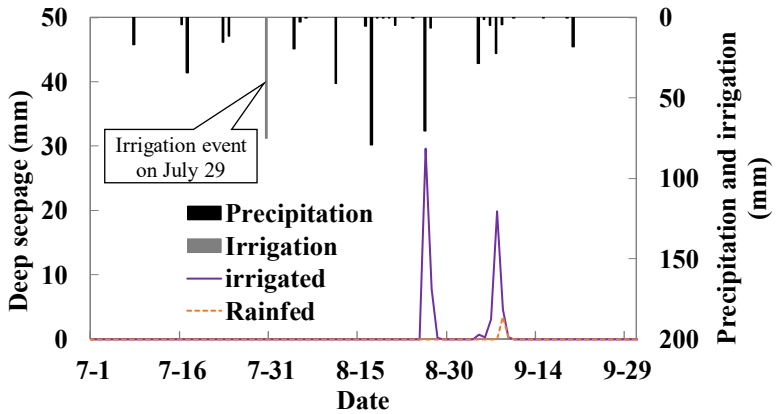

Figure 7. Comparison of deep seepage of soil water between irrigated and rainfed fields.

\subsection{Field water consumption}

The field water consumption in agriculture mainly includes three parts, namely, soil evaporation, plant transpiration and canopy interception evaporation. The change regularity of different water consumption processes is shown in Figure 8. In the early stage of maize growth, the ground coverage was low, and the field water consumption was mainly surface soil evaporation. With the growth of maize and the increase of leaf area index, plant transpiration gradually became the main process of water consumption in the field. The turning point of surface soil evaporation and plant transpiration was around July 8 when surface soil evaporation rapidly reduced and remained at a low level thereafter. Plant transpiration continued to increase after July 8 , by the middle of August, maize entered the most vigorous growth period, plant transpiration was also the largest. With the arrival of maturity, the leaf area index of maize gradually reduced and the plant transpiration decreased. Canopy interception evaporation of maize was correlated with precipitation and leaf area index, smaller in early growth stage and late mature stage and larger in vigorous growth period. According to the simulation results, the total field water consumption of maize during the growth period was about $314 \mathrm{~mm}$ (average value of irrigated and rainfed fields), in which, the ratio of surface soil evaporation, plant transpiration and canopy interception evaporation was about $34 \%, 58 \%$ and $8 \%$ respectively.

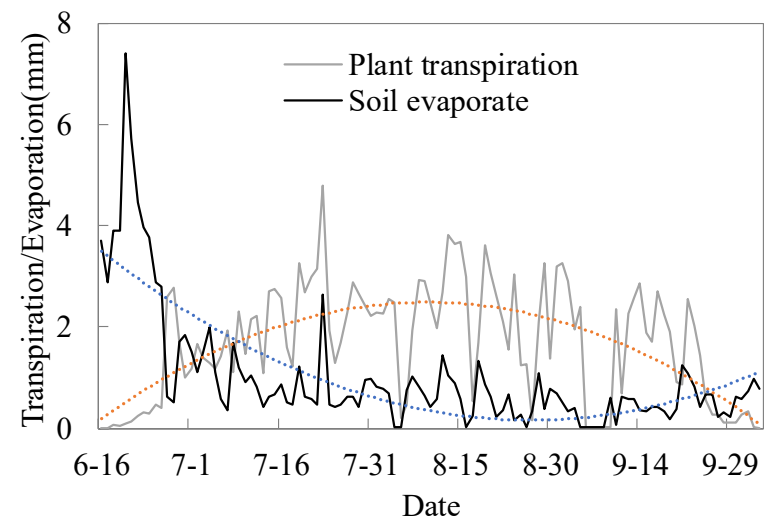

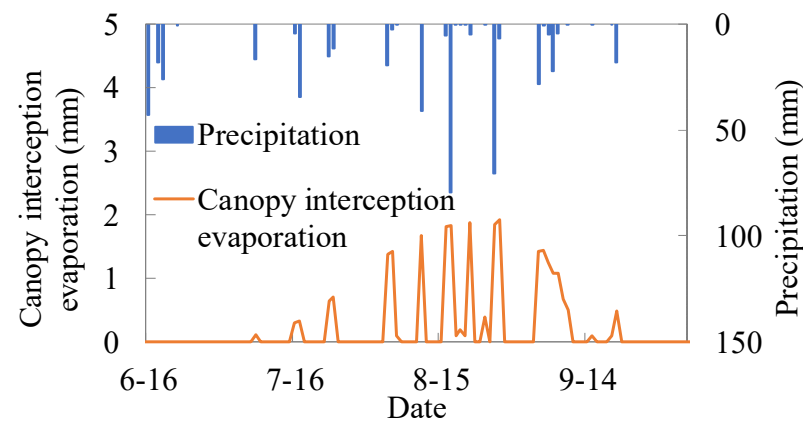

Figure 8. Dynamic processes of soil evaporation, plant transpiration and canopy interception evaporation during the maize growth period, taken the average values of irrigated and rainfed fields.

\section{Conclusion}

Experimental observations were carried out on the growth and water movement of a typical crop in BTH region, and the soil water process during the maize growth period was simulated by the soil water transformation model which was independently developed. Through the stimulation and calibration on the field water content change, the soil profile water content distribution at different moments, the change of maize leaf area index and plant height during the maize growth period, it was indicated that the soil water transformation model established can be applied to field-scale soil water process simulation in this region.

Through the simulation analysis of the soil water process, it is found that the total water consumption during the growth period of maize was about $314 \mathrm{~mm}$ under the meteorological condition in 2016 in BTH region, of which, the ratio of surface soil evaporation, plant transpiration and canopy evaporation was about 34\%, 58\% and $8 \%$ respectively. Deep seepage volume of soil water in farmland was closely related to the accumulation of soil water in the early stage, and the deep seepage would not occur until the water content was accumulated to a certain volume. In addition, irrigation in this experiment significantly affected the deep seepage of soil water, and the reason was that irrigation increased the soil water moisture. The quantitative analysis showed that, in this experiment, $85 \%$ of the $75 \mathrm{~mm}$ of irrigated water eventually returned to the groundwater through deep seepage instead of being utilized by crops.

In summary, soil water transformation is a complicated and comprehensive process that has close correlation with many factors, such as rainfall, meteorological changes, crop growth and irrigation activities. The soil water process during the maize growth period in 2016 was analyzed in this paper, which is favorable to exploring the regularity of soil water transformation under the condition of comprehensive factors. However, due to the complexity of soil water process, some conclusions may only reflect the scenarios under current specific meteorological conditions and irrigation activities, so the study can be carried out under multiple scenarios in the future. In addition, the field scale single underlying surface scenario was discussed in this 
paper, so in the future, the study on the regularity of agricultural water cycle and groundwater recharge under regional scale complex underlying surface can be further carried out on the basis of soil water model established in this paper.

\section{Acknowledgements}

We acknowledge the support from the National Key Research and Development Program of China (grant No. 2016YFC0401404), the National Natural Science Foundation of China (grant No. 51509264), and the National Natural Science Foundation of China (grant No. 51879066).

\section{References}

1. Z. Lei, H. Hu, and S. Yang. A review of soil water research. Advances in Water Science 10, 311318(1999).

2. D. Xiao and S. Wang. Comments on the progress and direction in soil water research. Ecology and Environmental Sciences 18(3), 1182-1188 (2009).

3. J. L. Monteith. Climate and the efficiency of crop production in Britain. Philosophical Transactions of Royal Society, London, B 281, 277-329(1977).

4. A. Robock, K. Y. Vinnikov, G. Srinivasan, J. K. Entin, S. E. Hollinger, N. A. Speranskaya, S. Liu, and A. Namkhai. The global soil moisture data bank. B. Am. Meteorol. Soc. 81(6), 1281-1299(2000).

5. K. A. McColl, S. H. Alemohammad, R. Akbar, A. G. Konings, S. Yueh, and D. Entekhabi. The global distribution and dynamics of surface soil moisture. Nat. Geosci. 10(2), 100-104(2017).

6. M. Sprenger, T. H. M. Volkmann, T. Blume, and M. Weiler. Estimating flow and transport parameters in the unsaturated zone with pore water stable isotopes. Hydrol. Earth Syst. Sci. 19(6), 2617-2635(2015).

7. M. D. Ankeny, M. Ahmed, T. C. Kaspar, and R. Horton. Simple field method determining unsaturated hydraulic conductivity. Soil Sci. Soc. Am. J. 55, 467470(1991).

8. S. Tamari, L. Bruckler, J. Halbertsma, and J. Chadoeuf. A simple method for determining soil hydraulic properties in the laboratory. Soil Sci. Soc. Am. J. 57(3), 642-651(1993).

9. M. R. Marshall, C. E. Ballard, Z. L. Frogbrook, I. Solloway, N. McIntyre, B. Reynolds, and H. S. Wheater. The impact of rural land management changes on soil hydraulic properties and runoff processes: results from experimental plots in upland UK. Hydrol. Process. 28(4), 2617-2629(2013).

10. N. Romano. Soil moisture at local scale: measurements and simulations. J. Hydrol. 516(6), 620(2014).

11. H. Fang, L. Sun, and Z. Tang. Effects of rainfall and slope on runoff, soil erosion and rill development: an experimental study using two loess soils. Hydrol. Process. 29(11), 2649-2658(2015).

12. R. Morbidelli, C. Saltalippi, A. Flammini, M. Cifrodelli, C. Corradini, and R. S. Govindaraju. Infiltration on sloping surfaces: Laboratory experimental evidence and implications for infiltration modeling. J. Hydrol. 523, 79-85(2015).

13. J. Peng, A. Loew, O. Merlin, and N. E. C. Verhoest. A review of spatial downscaling of satellite remotely sensed soil moisture. Rev. Geophys. 55, 341366(2017).

14. H. Asgarzadeh, M. R. Mosaddeghi, A. R. Dexter, A. A. Mahboubi, and M. R. Neyshabouri. Determination of soil available water for plants: consistency between laboratory and field measurements. Geoderma s226-227(1), 8-20(2014).

15. P. Scholl, D. Leitner, G. Kammerer, W. Loiskandl, H. P. Kaul, and G. Bodner. Root induced changes of effective 1D hydraulic properties in a soil column. Plant and Soil 381, 193-213(2014).

16. S. Moghadas, A. Gustafsson, P. Viklander, J. Marsalek, and M. Viklander. Laboratory study of infiltration into two frozen engineered (sandy) soils recommended for bioretention. Hydrol. Process. 30(8), 1251-1264(2016).

17. E. J. Coopersmith, M. H. Cosh, W. A. Petersen, J. Prueger, and J. J. Niemeier. Soil moisture model calibration and validation: an ARS watershed on the South Fork Iowa River. J. Hydrometeorol. 16(3), 1087-1101(2015).

18. J. Mohammadzadeh-Habili and M. Heidarpour. Application of the Green-Ampt model for infiltration into layered soils. J. Hydrol. 527, 824-832(2015).

19. K. T. Zeleke, M. Anwar, and D. L. Liu. Managing crop stubble during fallow period for soil water conservation: field experiment and modelling. Environ. Earth Sci. 72(9), 3317-3327(2014).

20. W. Mao, Y. Zhu, L. Shi, Z. Liu, H. Dai, and J. Yang. Modified unsaturated water flow model selection method and application to field experiments. Advances in Water Science 27, 231-239(2016).

21. X. Gao, C. Lu, Q. Luan, S. Zhang, J. Liu, and D. Han. Mapping Farmland-Soil Moisture at a Regional Scale Using a Distributed Hydrological Model: Case Study in the North China Plain. J. Irrig. Drain. Eng., 142(9), (2016).

22. C. Lu, D. Qin, J. Zhang, and R. Wang. MODCYCLEan object oriented modularized hydrological model I, theory and development." Journal of hydraulic engineering, 43, 1135-1145(2012).

23. J. Wang, C. Lu, Q. Sun, W. Xiao, G. Cao, H. Li, L. Yan, and B. Zhang. Simulating the hydrologic cycle in coal mining subsidence areas with a distributed hydrologic model. Sci. Rep., (2017).

24. J. Martinec. The degree-day factor for snowmeltrunoff forecasting. IAHS-AISH Publications, 51, 468-477(1960) 
25. C. Venetis. A study on the recession of unconfined aquifers. Bulletin of the International Association of Scientific Hydrology, 14(4), 119-125(1969).

26. E. C. Gilmore and R. S. Rogers. Heat units as a method of measuring maturity in corn. Agron. J., 50(10), 611-615 (1958). 